\title{
Thyroid autoimmunity occurs more frequently in women with breast cancer compared to women with colorectal cancer and controls but it has no impact on relapse-free and overall survival
}

\author{
JAN JISKRA ${ }^{1}$, JAROSLAVA BARKMANOVA ${ }^{2}$, ZDENKA LIMANOVA ${ }^{1}$, VERA LáNSKá ${ }^{3}$, \\ DANIEL SMUTEK $^{1}$, ELISKA POTLUKOVA ${ }^{1}$ and MARIE ANTOSOVA ${ }^{1}$
}

\begin{abstract}
${ }^{1}$ Third Clinic of Medicine of the First Faculty of Medicine, Charles University, U Nemocnice 1, 12808 Prague $2,{ }^{2}$ Clinic of Oncology of the First Faculty of Medicine, Charles University, U Nemocnice 2, 12808 Prague $2 ;{ }^{3}$ Institute for Clinical and Experimental Medicine, Videnska 1958/9, 14021 Prague 4, Czech Republic.
\end{abstract}

Received July 30, 2007; Accepted September 4, 2007

\begin{abstract}
The aim of the study was to compare the prevalence of autoimmune thyroid diseases (AITD) in patients with breast and colorectal cancer and controls and to evaluate the impact of AITD on the outcome of patients with breast cancer. Serum levels of TSH (thyroid-stimulating hormone), FT4 (free thyroxine), TPOAb (antibodies to thyroid peroxidase), $\mathrm{TgAb}$ (antibodies to thyroglobulin), selenium and prolactin were investigated in 210 randomly chosen women (89 with breast cancer and 72 with colorectal cancer after breast or abdominal surgery and 49 controls without oncological diseases). Eighty-four women with breast cancer were followed for a median of 136.0 months. The prevalence of positive titres of TPOAb $\left(>60 \mathrm{kIU} .1^{-1}\right)$ was higher in the women with breast cancer as compared to positive titres in women with colorectal cancer and the controls (29.8 vs. 12.5 and $12.2 \%$, respectively, $\mathrm{P}=0.016$ and 0.036 , respectively). Similarly, the prevalence of clinical, ultrasound and laboratory documented AITD was higher in women with breast cancer as compared to that in women with colorectal cancer and the controls (35.7 vs. 18.1 and $16.3 \%$, respectively, $\mathrm{P}=0.014$ and 0.029 , respectively). We did not find any prognostic significance of FT4, TSH, TgAb, TPOAb, prolactin and the presence of AITD on relapse-free and overall survival among women with breast cancer. A negative prognostic significance of body mass index and serum levels of selenium on relapsefree survival was found. In conclusion, the prevalence of
\end{abstract}

Correspondence to: Dr Jan Jiskra, 3 Interni Klinika 1, LF UK a VFN, U Nemocnice 1, 12808 Prague 2, Czech Republic

E-mail: jan.jiskra@lf1.cuni.cz

Key words: breast cancer, thyroid autoimmunity, thyroidstimulating hormone, antibodies to thyroid peroxidase, antibodies to thyroglobulin, selenium euthyroid AITD was higher in women with breast cancer as compared to euthyroid AITD in women with colorectal cancer and controls. The presence of AITD did not have an impact on the outcome of women with breast cancer.

\section{Introduction}

The relationship between breast cancer and autoimmune (AITD) and non-autoimmune (non-AITD) thyroid diseases is not fully understood. A sonographic enlargement of the thyroid gland (1), an increased rate of positive serum levels of antibodies to thyroid peroxidase (15-38\% according to several studies) and a higher frequency of AITD (2-6) were found in women with breast cancer in comparison with sex- and agematched healthy women. Moreover, some studies suggested that the presence of AITD may be associated with an improvement in the outcome of women with breast cancer $(3,7)$. In contrast, other reports did not confirm such associations (8-11). Unfortunately, with the exception of the study by Smyth et al (3), there are no additional prospective studies concerning a potential influence of AITD and non-AITD on the outcome of women with breast cancer.

Sufficient iodine and selenium intake is necessary for thyroid hormones synthesis and its action. However, some reports showed that selenium deficiency may be a risk factor for several oncological diseases (12-15).

Therefore, there are three main topics of research concerning the relationship between the thyroid gland and breast cancer. First, we tried to ascertain whether the prevalence of thyroid disorders increased only in women with breast cancer or also in other malignant diseases. Second, we tried to elucidate whether the thyroid disorders have an impact on the outcome of patients with breast cancer and third, if there is any causal link between the two diseases.

We compared the prevalence of thyroid disorders in three groups of women: with breast cancer, with colorectal cancer and without oncological diseases (controls). This study provided a basis for a prospective follow-up study which focused on a possible prognostic significance of AITD and 
Table I. Demographic and oncological characteristics of the patients with breast and colorectal cancer and controls at the baseline of the study.

\begin{tabular}{|c|c|c|c|}
\hline \multirow[t]{2}{*}{ Characteristic } & \multicolumn{3}{|c|}{ Value } \\
\hline & Breast cancer & Colorectal cancer & Controls \\
\hline No. & $84^{\mathrm{a}}$ & 72 & 49 \\
\hline \multicolumn{4}{|l|}{ Age - years } \\
\hline Mean $\pm \mathrm{SD}$ & $64.7 \pm 11.4$ & $67.5 \pm 10.5$ & $68.3 \pm 12.9$ \\
\hline Range & $41-89$ & $44-85$ & $39-90$ \\
\hline \multicolumn{4}{|l|}{ Sex - no. $(\%)$} \\
\hline Female & $84(100)$ & $72(100)$ & $49(100)$ \\
\hline Male & $0(0)$ & $0(0)$ & $0(0)$ \\
\hline \multicolumn{4}{|l|}{ TNM stage - no. $(\%)$} \\
\hline $\mathrm{T} 1$ & $37(44)$ & $16(23)$ & - \\
\hline $\mathrm{T} 2$ & $41(49)$ & $21(30)$ & - \\
\hline $\mathrm{T} 3$ & $6(7)$ & $31(43)$ & - \\
\hline $\mathrm{T} 4$ & $0(0)$ & $4(6)$ & - \\
\hline N0 & $53(63)$ & $60(84)$ & - \\
\hline N1 & $28(33)$ & $9(12)$ & - \\
\hline $\mathrm{N} 2$ & $3(4)$ & $3(4)$ & - \\
\hline M0 & $83(99)$ & $69(96)$ & - \\
\hline M1 & $1(1)$ & $3(4)$ & - \\
\hline \multicolumn{4}{|l|}{ Therapy - no. (\%) } \\
\hline Surgery & $84(100)$ & $72(100)$ & - \\
\hline Chemotherapy & $64(76)$ & $56(78)$ & - \\
\hline Postoperative radiotherapy & $17(20)$ & $8(11)$ & - \\
\hline Hormonal therapy & $69(82)$ & $0(0)$ & - \\
\hline Tamoxifen only & $54(64)$ & - & - \\
\hline Tamoxifen with other hormonal therapy ${ }^{\mathrm{b}}$ & $10(12)$ & & \\
\hline Other hormonal therapy only ${ }^{b}$ & $5(6)$ & & \\
\hline
\end{tabular}

${ }^{a}$ Thirty-eight pre-menopausal and 46 post-menopausal; banastrozol, fulvestrant, letrozol, goserelin; SD, standard deviation. At the time of diagnosis the expression of estrogen and progesterone receptors in breast cancer tissue was not investigated as a routine method.

serum levels of prolactin and selenium on the outcome of patients with breast cancer.

\section{Materials and methods}

Patients. One hundred and sixty-one randomly chosen female patients with oncological diseases were enrolled in the study. Of these, 89 patients had breast cancer and $72 \mathrm{had}$ colorectal cancer after surgery. Five women from the breast cancer group were excluded because of insufficient data. Eighty-four women with breast cancer were followed for a median of 136.0 months (range: 19.0 to 261.0 , 95\% confidence interval 126.2 to 145.8 ) after breast surgery. Moreover, 49 age-comparable women with several nononcological diseases (ischemic heart disease, arterial hypertension, cerebral stroke, thromboembolic disease, chronic bronchitis and type 2 diabetes mellitus) admitted to the medical department were enrolled as a control group. Table I shows demographic and oncological characteristics of the patients and controls at the baseline of the study. Unfortunately, at the time of diagnosis the expression of estrogen and progesterone receptors in breast cancer tissue was not investigated as a routine method. Patients were followed-up by standardized medical check-ups. Clinical evaluation consisted of a medical history, physical examination and basic blood chemical analyses and a cell blood count at three-month intervals. At six-month intervals, serum tumour markers CEA (carcinoembryonal antigen) and CA 15-3 were measured, a breast and abdominal ultrasound and chest X-ray were performed.

The study was approved by the local ethics committee and a written informed consent was obtained from all participants.

Analytical procedures. Fasting blood samples were obtained from all subjects, processed to blood serum and stored at $4^{\circ} \mathrm{C}$. Within a maximum of $12 \mathrm{~h}$, the serum concentration of the following parameters was measured by the method of chemiluminiscence (analyser Centaur-Bayer) in all samples: thyroidstimulating hormone (TSH), free thyroxine (FT4), antibodies 
Table II. Criteria for the diagnosis of thyroid diseases.

\begin{tabular}{ll}
\hline Disease & Features \\
\hline
\end{tabular}

$\begin{array}{ll}\text { Healthy thyroid gland }^{\mathrm{a}} & \text { Normal TSH and FT4 } \\ & \text { Negative TPOAb and TgAb }\end{array}$

Autoimmune thyroid diseases (AITD)

$\begin{array}{ll}\text { Autoimmune thyroiditis }^{\mathrm{b}} & \begin{array}{l}\text { Positive TPOAb and/or TgAb } \\ \text { TSH }>4.0 \text { mIU. } .^{-1}\end{array} \\ & \text { Decreased echogenity and non- } \\ \text { homogeneous thyroid structure } & \\ & \text { ultrasound } \\ & \text { Positive TRAK } \\ & \text { TSH }<0.4 \text { mIU. }{ }^{-1} \\ \text { Graves' disease }^{\mathrm{a}} & \text { Decreased echogenity, non- } \\ & \text { homogeneous thyroid structure } \\ & \text { and increased perfusion on } \\ & \text { ultrasound }\end{array}$

Non-autoimmune thyroid diseases (non-AITD)

Isolated nodule ${ }^{\mathrm{a}}$

Negative TPOAb and TgAb and/ or TRAK

TSH normal or $<0.4$ mIU..$^{-1}$

Primary normal echogenity and homogeneous structure, isolated thyroid nodule

Multiple nodules ${ }^{\mathrm{a}}$

Negative TPOAb and TgAb and/
or TRAK
TSH normal or $<0.4$ mIU.1 ${ }^{-1}$
Primary normal echogenity and
homogeneous structure, multiple
thyroid nodules

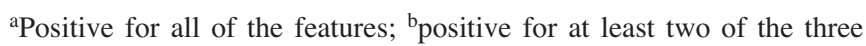
features; TSH, serum levels of thyroid-stimulating hormone (mIU. $\left.1^{-1}\right)$; $\mathrm{TgAb}$, serum levels of antibodies to thyroglobulin ( $\mathrm{kIU} . \mathrm{l}^{-1}$ ); TPOAb, serum levels of antibodies to thyroid peroxidase (kIU. $\left.\mathrm{l}^{-1}\right)$; TRAK $\left(\mathrm{IU} . \mathrm{l}^{-1}\right)$, antibodies to TSH-receptor.

to thyroglobulin ( $\mathrm{TgAb}$ ), antibodies to thyroid peroxidase (TPOAb), prolactin, carcinoembryonal antigen (CEA) and tumour marker CA 15-3 (CA 15-3). In 65 women in the breast and 29 in the colorectal cancer group nuclear absorbefacient spectroscopy was used to determine the serum levels of selenium. The following ranges were regarded as physiological: TSH, 0.4-4.0 mIU.1-1 (16,17); FT4, 9.8-23.1 pmol. . $^{-1}$; TgAb,

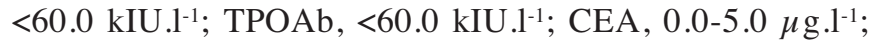
CA 15-3, 0.0-31.0 kIU.1-1; prolactin, 1.8-20.3 $\mu \mathrm{g} . \mathrm{l}^{-1}$ and selenium, 46.0-143.0 $\mu \mathrm{g} . \mathrm{l}^{-1}$.

The median time from breast surgery to the blood sample collection was 29.5 months (range: 4.0 to 111.0 , 95\% confidence interval: 21.8 to 37.2 ). In the subgroup of patients with recurrent breast cancer, the median time from the blood sample collection to relapse was 16.0 months (range: -49.0 to
96.0, 95\% confidence interval: -1.0 to 33.0$)$. In two patients, the relapse occurred before the blood sample was taken (49.0 and 25.0 months). All patients with pathological thyroid laboratory tests were seen by an endocrinologist and underwent a thyroid ultrasound in order to confirm or exclude thyroid disease. Apart from the normal thyroid, four types of thyroid disorders were established (Table II).

At the time of the blood sample collection, two patients in the breast but none in the colorectal cancer group were treated with levothyroxine. No patients in either group were treated with carbimazole, thiamazole or propylthiouracyl. Two patients in the breast and one in the colorectal cancer group were treated with levothyroxine in the past. Similarly, three patients in the breast and one in the colorectal cancer group were treated with carbimazole, thiamazole or propylthiouracyl in the past. During follow-up, treatment with levothyroxine was started in six patients (five due to overt or subclinical hypothyroidism and one due to multiple thyroid nodules). Carbimazole was started in one patient with breast cancer and Graves' disease.

Thyroid ultrasound. A sonographic examination of the thyroid gland was performed by ultrasound equipment (EnVisor by Phillips) with an 8-MHz linear probe (model PLF-805ST), allowing a maximum examination depth of $40 \mathrm{~mm}$ at a frame rate of $19 \mathrm{~Hz}$. The volume of the thyroid gland and the echogenity, structure, presence of nodules and perfusion were also evaluated. The volume of each thyroid lobe was calculated as length (millimetres) $\mathrm{x}$ width (millimetres) $\mathrm{x}$ depth (millimetres) x 0.479 .

Statistical analysis. The Chi-square test, t-test, Mann-Whitney test, ANOVA (Analysis of variance) and Kruskal-Wallis test were used to compare the proportions, means and medians of several variables between the groups of patients (breast and colorectal cancer and controls, with vs. without recurrence of disease, with vs. without AITD). The primary end points for all the patients with breast cancer were relapse-free and overall survival from the time of the breast surgery. Relapsefree survival was calculated from the date of the breast surgery to the date on which relapse was first documented or on which death without documented relapse occurred. Follow-up data were updated on July 1, 2006 and data from patients who had not had a relapse by that date were censored at the time of the last clinic visit. Overall survival was calculated from the initiation of treatment to the date of death or last contact. Probabilities of relapse-free and overall survival were estimated by the product-limit survival analysis (Kaplan-Meier method). The Cox regression model was used for the analysis of the prognostic significance of various variables measured at the baseline of the study on relapse-free and overall survival. Wald statistics was used to test the effect of various covariates. All reported $\mathrm{P}$-values are two-sided and $\mathrm{P}<0.05$ was considered statistically significant. Statistical software SYSTAT 10 was used for data analysis.

\section{Results}

A significantly higher prevalence of positive serum levels of TPOAb (>60 kIU. $\left.{ }^{-1}\right)$ was found in patients with breast cancer 


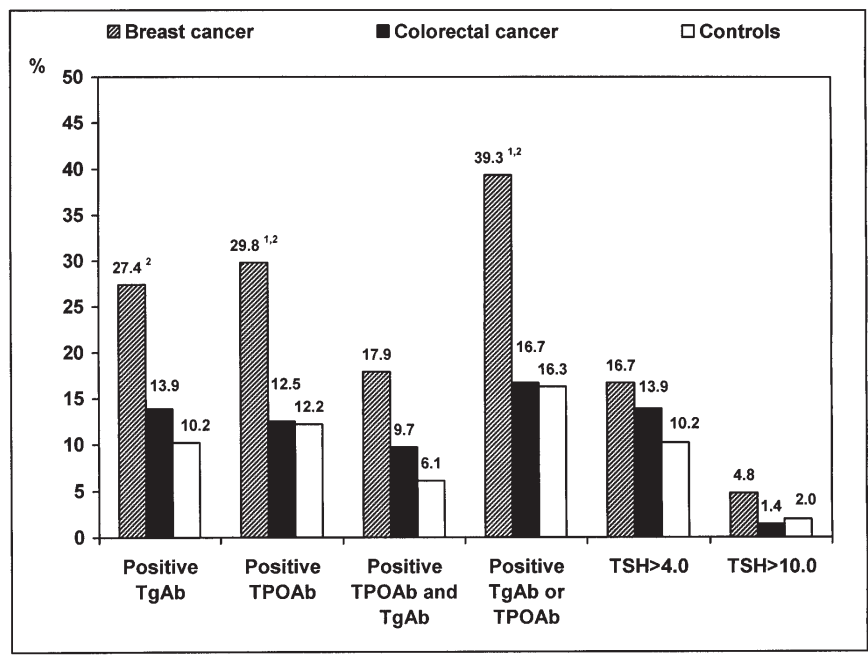

Figure 1. Prevalence of positive serum levels $\left(>60 \mathrm{kIU}^{-1^{-1}}\right)$ of antibodies to thyroid peroxidase (TPOAb), antibodies to thyroglobulin ( $\mathrm{TgAb}$ ) and increased serum levels of thyroid stimulating hormone (TSH mIU.1-1 $)$ in patients with breast cancer, colorectal cancer and controls. Chi-square test: ${ }^{1}$ statistical significant differences as compared to colorectal cancer $(\mathrm{P}<0.05)$, ${ }^{2}$ statistical significant differences as compared to controls $(\mathrm{P}<0.05)$.

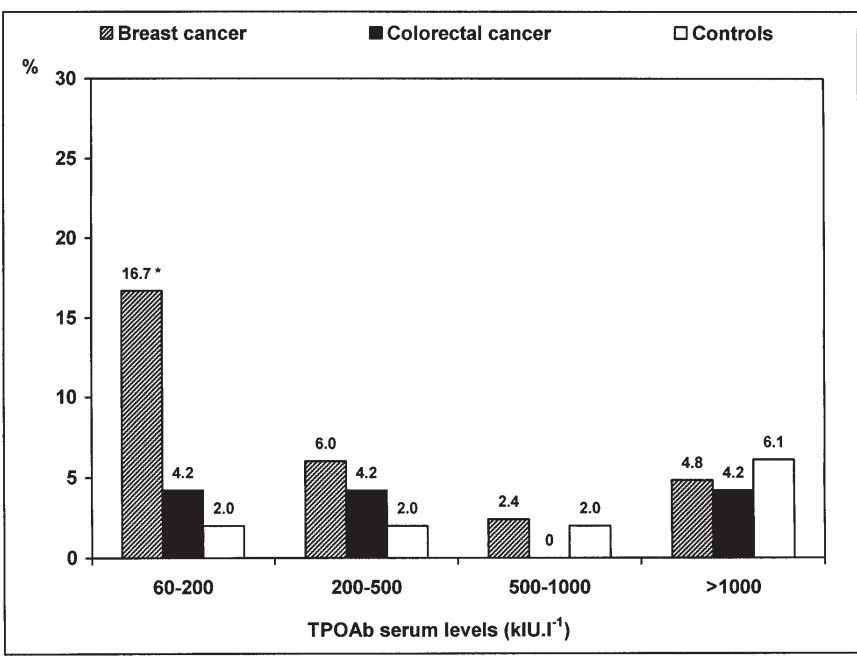

Figure 2. Prevalence of positive serum levels $\left(>60 \mathrm{kIU} .1^{-1}\right)$ of antibodies to thyroid peroxidase (TPOAb) in patients with breast cancer, colorectal cancer and controls depending on the degree of positive titres. Chi-square test: *significant differences as compared to colorectal cancer and controls $(\mathrm{P}<0.05)$.

as compared to patients with colorectal cancer and controls (29.8 vs. 12.5 and $12.2 \%$, respectively, $\mathrm{P}=0.016$ and 0.036 , respectively) (Table III, Fig. 1). Similarly, the prevalence of positive serum levels of $\mathrm{TgAb}\left(>60 \mathrm{kIU}^{-1}{ }^{-1}\right)$ was higher in women with breast cancer as compared to the controls (27.4 vs. $10.2 \%, P=0.034)$, the difference between breast and colorectal cancer did not reach statistical significance (27.4 vs. $13.9 \%, \mathrm{P}=0.063$ ) (Table III, Fig. 1). In contrast to $\mathrm{TgAb}$, a higher prevalence of positive TPOAb in breast cancer as compared to that in colorectal cancer and the controls was especially observed in patients with slightly increased titres (60-200 kIU.1-1 $)$, whereas in patients with medium (200-500

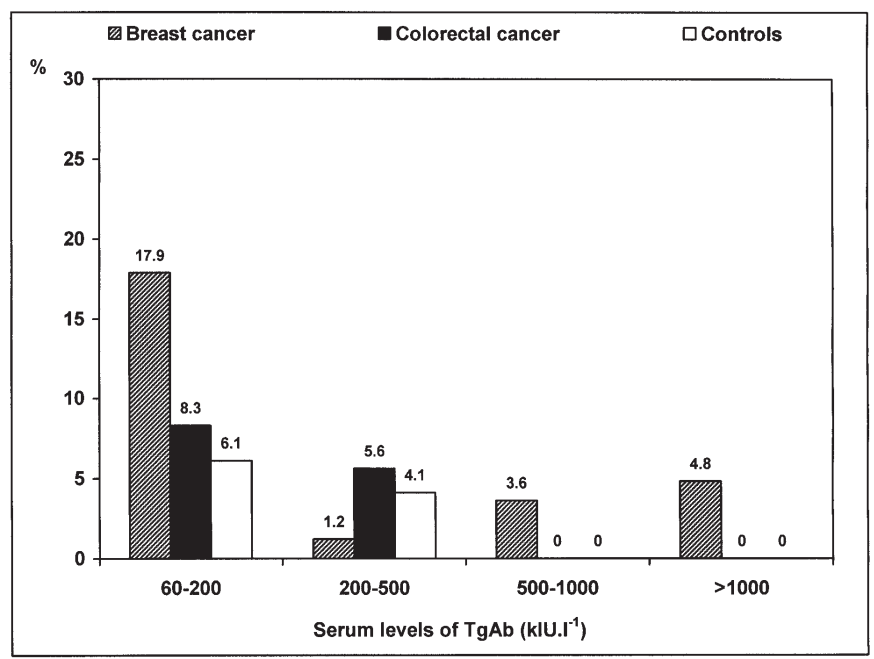

Figure 3. Prevalence of positive serum levels $\left(>60\right.$ kIU.1 $\left.{ }^{-1}\right)$ of antibodies to thyroglobulin in patients with breast cancer, colorectal cancer and controls depending on the degree of positive titres. Chi-square test: no significant differences between the groups of patients and controls were found.

and 500-1000 kIU.1 $\left.{ }^{-1}\right)$ and very high (>1000 kIU.1 $\left.{ }^{-1}\right)$ titres there were no significant differences (Figs. 2 and 3). The mean or median of the serum levels of TSH, FT4, TPOAb, $\mathrm{TgAb}$ and prolactin did not significantly differ between the groups (Table III). Pathological thyroid laboratory tests were detected in $39 / 84$ patients $(46.4 \%)$ with breast cancer as compared to $20 / 72$ patients $(27.8 \%)$ with colorectal cancer $(\mathrm{P}=0.026)$ and $10 / 49(20.0 \%)$ controls $(\mathrm{P}=0.005)$. All these patients underwent a thyroid ultrasound and clinical examination in order to confirm the diagnosis. Consequently, AITD was diagnosed in 30/84 patients ( 29 with autoimmune thyroiditis and one with Graves' disease) (35.7\%) with breast cancer as compared to $13 / 72$ patients (all autoimmune thyroiditis) $(18.1 \%)$ with colorectal cancer $(\mathrm{P}=0.014)$ and $8 / 49(16.3 \%)$ (all autoimmune thyroiditis) in the control group $(\mathrm{P}=0.029)$ (Table III). Overt or subclinical hypothyroidism with TSH $>4.0$ mIU..$^{-1}$ and normal FT4 serum levels was diagnosed in $14 / 84$ patients $(16.7 \%)$ with breast cancer, $10 / 72(13.9 \%)$ with colorectal cancer and 5/49 (10.2\%) of the controls (the differences did not reach statistical significance) (Table III, Fig. 1).

Among the 18 patients with thyroid laboratory abnormalities but who lacked ultrasound signs of AITD, multiple or isolated thyroid nodules were found in $3 / 9$ patients with breast cancer, in $2 / 7$ with colorectal cancer and in $1 / 2$ of the controls. Therefore, thyroid disease (AITD or non-AITD) was diagnosed in $33 / 84$ patients $(39.3 \%)$ with breast cancer as compared to $15 / 72$ patients $(20.8 \%)$ with colorectal cancer $(\mathrm{P}=0.021)$ and $9 / 49(18.4 \%)$ controls $(\mathrm{P}=0.021)$ (Table III). No significant difference of the thyroid volume measured by ultrasound was found between women with breast and colorectal cancer.

Eighty-four women with breast cancer were followed for a median of 136.0 months (range: 19.0 to $261.0,95 \%$ confidence interval: 145.8 to 126.2 ) after the breast surgery. Thirty patients $(35.7 \%)$ had a recurrence of breast cancer (12 had local metastasis and 18 had a metastasis to the liver, 
Table III. Comparison of thyroid parameters in patients with breast and colorectal cancer and controls.

\begin{tabular}{|c|c|c|c|c|}
\hline & Breast cancer & Colorectal cancer & Controls & P-value \\
\hline No. & 84 & 72 & 49 & \\
\hline Age - years & $64.7 \pm 11.4$ & $67.5 \pm 10.5$ & $68.3 \pm 12.9$ & $\begin{array}{l}P_{1}=0.110^{a} \\
P_{2}=0.102^{a}\end{array}$ \\
\hline FT4 & $15.647 \pm 4.857$ & $14.876 \pm 2.653$ & $15.2 \pm 3.1$ & $\begin{array}{l}\mathrm{P}_{1}=0.230^{\mathrm{a}} \\
\mathrm{P}_{2}=0.303^{\mathrm{a}}\end{array}$ \\
\hline TSH & $\begin{array}{c}1.61 \\
(107.89-0.02)\end{array}$ & $\begin{array}{c}1.68 \\
(12.58-0.07)\end{array}$ & $\begin{array}{c}1.52 \\
(0.96-2.66)\end{array}$ & $\begin{array}{l}P_{1}=0.808^{b} \\
P_{2}=0.767^{b}\end{array}$ \\
\hline Positive TPOAb - no. (\%) & $25(29.8)$ & $9(12.5)$ & $6(12.2)$ & $\begin{array}{l}\mathrm{P}_{1}=0.016^{\mathrm{c}} \\
\mathrm{P}_{2}=0.036^{\mathrm{c}}\end{array}$ \\
\hline Positive $\mathrm{TgAb}-$ no. (\%) & $23(27.4)$ & $10(13.9)$ & $5(10.2)$ & $\begin{array}{l}\mathrm{P}_{1}=0.063^{\mathrm{c}} \\
\mathrm{P}_{2}=0.034^{\mathrm{c}}\end{array}$ \\
\hline Positive TPOAb or TgAb - no. (\%) & $33(39.3)$ & $12(16.7)$ & $8(16.3)$ & $\begin{array}{l}\mathrm{P}_{1}=0.003^{\mathrm{c}} \\
\mathrm{P}_{2}=0.010^{\mathrm{c}}\end{array}$ \\
\hline Positive TPOAB and TgAb - no. (\%) & $15(17.9)$ & $7(9.7)$ & $3(6.1)$ & $\begin{array}{l}\mathrm{P}_{1}=0.221^{\mathrm{c}} \\
\mathrm{P}_{2}=0.100^{\mathrm{c}}\end{array}$ \\
\hline TSH >4.0 mIU.1. $.^{-1}-$ no. $(\%)$ & $14(16.7)$ & $10(13.9)$ & $5(10.2)$ & $\begin{array}{l}P_{1}=0.797^{\mathrm{c}} \\
\mathrm{P}_{2}=0.441^{\mathrm{c}}\end{array}$ \\
\hline TSH > 10.0 mIU.1. ${ }^{-1}-$ no. $(\%)$ & $4(4.8)$ & $1(1.4)$ & $1(2.0)$ & $\begin{array}{l}P_{1}=0.461^{c} \\
P_{2}=0.746^{c}\end{array}$ \\
\hline $\begin{array}{l}\text { TSH }>4.0 \text { mIU } .1 .^{-1} \text { and } \\
\text { positive TPOAb - no. }(\%)\end{array}$ & $8(9.5)$ & $5(6.9)$ & $3(5.6)$ & $\begin{array}{l}\mathrm{P}_{1}=0.771^{\mathrm{c}} \\
\mathrm{P}_{2}=0.718^{\mathrm{c}}\end{array}$ \\
\hline AITD - no. (\%) & $30(35.7)$ & $13(18.1)$ & $8(16.3)$ & $\begin{array}{l}\mathrm{P}_{1}=0.014^{\mathrm{c}} \\
\mathrm{P}_{2}=0.029^{\mathrm{c}}\end{array}$ \\
\hline AITD or non-AITD - no. (\%) & $33(39.3)$ & $15(20.8)$ & $9(18.4)$ & $\begin{array}{l}\mathrm{P}_{1}=0.021^{\mathrm{c}} \\
\mathrm{P}_{2}=0.021^{\mathrm{c}}\end{array}$ \\
\hline Prolactin & $8.643 \pm 5.079$ & $9.875 \pm 3.573$ & Not investigated & $0.464^{\mathrm{d}}$ \\
\hline Selenium & $\begin{array}{c}72.257 \pm 18.028 \\
(\text { no. } 65)\end{array}$ & $\begin{array}{l}70.41 \pm 18.78 \\
\quad(\text { no. } 29)\end{array}$ & Not investigated & $0.413^{\mathrm{d}}$ \\
\hline $\begin{array}{l}\text { Thyroid volume measured } \\
\text { by ultrasound (ml) }\end{array}$ & $\begin{array}{c}8.93(5.36-13.77) \\
\quad(\text { no. 39) }\end{array}$ & $\begin{array}{c}8.48(4.06-13.61) \\
(\text { no. } 20)\end{array}$ & Not evaluated & $0.803^{\mathrm{e}}$ \\
\hline
\end{tabular}

${ }^{\mathrm{a} A N O V A}$ (Analysis of variance), expressed as mean $\pm \mathrm{SD}$; ${ }^{\mathrm{b} K r u s k a l-W a l l i s ~ t e s t, ~ e x p r e s s e d ~ a s ~ m e d i a n ~(m a x i m u m-m i n i m u m) ; ~}{ }^{\mathrm{c}} \mathrm{Chi}-\mathrm{square}$ test;

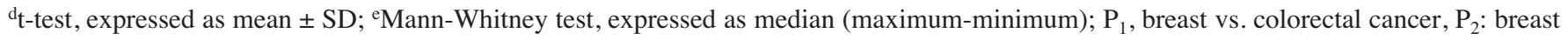
cancer vs. controls; FT4, serum levels of free thyroxine (9.8-23.1 pmol.1.1-1); TSH, serum levels of thyroid-stimulating hormone (mIU. $\left.1^{-1}\right)$; TgAb, serum levels of antibodies to thyroglobulin (cut-off $60 \mathrm{kIU.1}{ }^{-1}$ ); TPOAb, serum levels of antibodies to thyroid peroxidase (cut-off $60 \mathrm{kIU} .1^{-1}$ ); prolactin, serum levels of prolactin $\left(\mu \mathrm{g} .1^{-1}\right)$; selenium, serum levels of selenium $\left(\mu \mathrm{g} .1^{-1}\right)$; AITD, clinical, laboratory and ultrasound documented autoimmune thyroid disease; non-AITD, non-autoimmune thyroid disease.

bone or brain), 10 (11.9\%) died of breast cancer and $1(1.2 \%)$ died without a documented relapse of the disease.

At a median follow-up of 136.0 months, the proportion of patients with a recurrence of breast cancer did not significantly differ from groups with and without AITD (8/30 patients, $26.7 \%$ vs. $14 / 54$ patients $-25.9 \%$ ).
Probabilities of relapse-free and overall survival were estimated by the product-limit survival analysis (Kaplan-Meier method). Both the estimated relapse-free and estimated overall survival did not show any significant differences between the patients with and without AITD (Fig. 4) nor between the patients with and without a thyroid disease (AITD or non- 


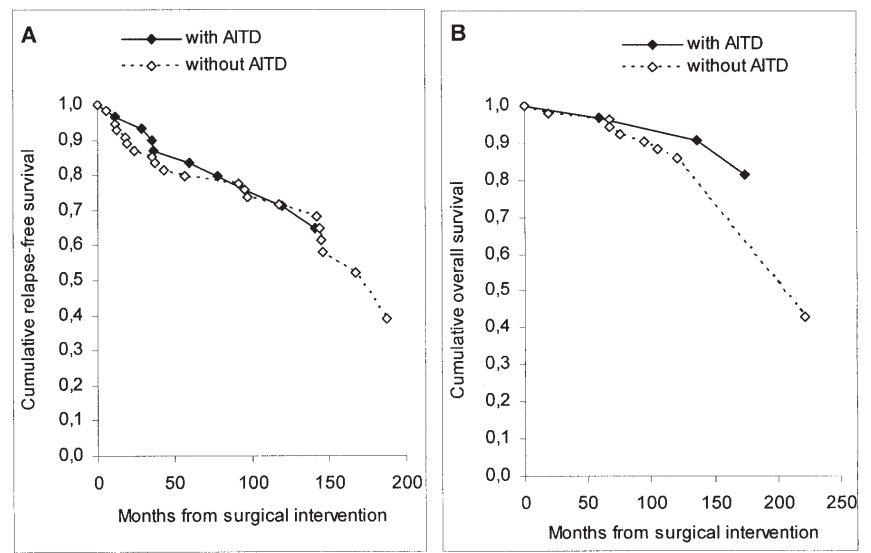

Figure 4. Probabilities of relapse-free (A) and overall survival (B) estimated by the product-limit survival analysis (Kaplan-Meier method). Both relapsefree and overall survival did not show significant differences among patients with and without autoimmune thyroid diseases (AITD).

AITD). Similarly, the estimated relapse-free and estimated overall survival did not differ between the patients with and without positive serum levels of TgAb or TPOAb (documented only by laboratory tests).

The Cox regression model was used for an analysis of the prognostic significance of various variables measured at the baseline of the study on relapse-free and overall survival (Table IV). Negative prognostic significances of increased body mass index (BMI) (regression coefficient 0.202, standard error $0.087, \mathrm{P}=0.02$ ) and increased serum levels of selenium (regression coefficient 0.028, standard error 0.009 , $\mathrm{P}=0.0025$ ) on relapse-free survival were found. However, an influence of BMI on overall survival was not verified. Similarly, a higher basal BMI $(30.506 \pm 3.236$ vs. 25.373 \pm 4.744 , $\mathrm{P}=0.004)$ and higher basal serum levels of selenium (81.036 \pm $18.245, \mathrm{n}=23$ vs. $67.449 \pm 16.181, \mathrm{n}=42, \mathrm{P}=0.003$ ) were found in patients with a relapse of the disease as compared to patients without a documented recurrence (Table V).

On the other hand, no significant differences in the proportion of recurrences between patients with and without AITD, with and without positive serum levels of TPOAb and/or $\mathrm{TgAb}$ and normal or elevated serum TSH levels were found. Accordingly, no significant influences of the serum levels of FT4, TSH, TgAb, TPOAb and prolactin and of the thyroid volume on relapse-free and overall survival were found.

There was a trend of negative prognostic significance of increased serum levels of CEA (regression coefficient 0.182, standard error $0.095, \mathrm{P}=0.055$ ) on relapse-free survival (Table IV). Similarly, increased serum levels of CA 15-3 at the baseline of the study had significantly negative prognostic significance on the overall survival (regression coefficient 0.134, standard error 0.057, $\mathrm{P}=0.018$ ) (Table IV).

\section{Discussion}

Our findings of a high prevalence of thyroid antibodies in women with breast cancer were in concordance with the results of most previous studies $(2-6,18)$. As shown above, only a few reports did not confirm this association (8-11). Our study was one of the first to compare the prevalence of thyroid antibodies

Table IV. Cox regression model of relapse-free survival and overall survival.

\begin{tabular}{|c|c|c|c|c|c|c|c|}
\hline \multirow[b]{2}{*}{ Variable } & \multirow[b]{2}{*}{$\begin{array}{l}\text { No. of } \\
\text { patients }\end{array}$} & \multicolumn{3}{|c|}{ Relapse-free survival } & \multicolumn{3}{|c|}{ Overall survival } \\
\hline & & $\begin{array}{l}\text { Regression } \\
\text { coefficient }\end{array}$ & $\begin{array}{l}\text { Standard } \\
\text { error }\end{array}$ & $\begin{array}{l}\mathrm{P} \text { (Wald } \\
\text { statistic) }\end{array}$ & $\begin{array}{l}\text { Regression } \\
\text { coefficient }\end{array}$ & $\begin{array}{l}\text { Standard } \\
\text { error }\end{array}$ & $\begin{array}{l}\mathrm{P} \text { (Wald } \\
\text { statistic) }\end{array}$ \\
\hline Age & 84 & 0.001 & 0.017 & 0.947 & 0.009 & 0.029 & 0.757 \\
\hline BMI & 84 & 0.202 & 0.087 & 0.020 & -0.012 & 0.207 & 0.955 \\
\hline FT4 & 84 & -0.010 & 0.077 & 0.612 & -0.043 & 0.087 & 0.604 \\
\hline TSH & 84 & 0.006 & 0.011 & 0.572 & 0.016 & 0.010 & 0.129 \\
\hline $\mathrm{TgAb}$ & 84 & -0.001 & 0.001 & 0.307 & 0.000 & 0.001 & 0.599 \\
\hline TPOAb & 84 & -0.000 & 0.000 & 0.728 & 0.000 & 0.000 & 0.583 \\
\hline Thyroid volume & 39 & -0.377 & 0.199 & 0.127 & -0.433 & 0.291 & 0.136 \\
\hline Prolactin & 31 & 0.091 & 0.061 & 0.135 & -0.043 & 0.238 & 0.858 \\
\hline Selenium & 65 & 0.028 & 0.009 & 0.0025 & 0.025 & 0.018 & 0.158 \\
\hline CEA & 68 & 0.182 & 0.095 & 0.055 & 0.203 & 0.162 & 0.208 \\
\hline CA $15-3$ & 67 & 0.052 & 0.029 & 0.074 & 0.134 & 0.057 & 0.018 \\
\hline
\end{tabular}

FT4, serum levels of free thyroxine (9.8-23.1 pmol.1-1 ${ }^{-1}$; TSH, serum levels of thyroid-stimulating hormone (mIU.1 . $^{-1}$ ); TgAb, serum levels of antibodies to thyroglobulin $\left(\mathrm{kIU} . \mathrm{l}^{-1}\right)$; TPOAb, serum levels of antibodies to thyroid peroxidase (kIU.1 ${ }^{-1}$ ); prolactin, serum levels of prolactin $\left(\mu \mathrm{g} . \mathrm{l}^{-1}\right)$; selenium, serum levels of selenium $\left(\mu \mathrm{g} . \mathrm{l}^{-1}\right)$; CEA, serum levels of carcinoembryonal antigen $\left(\mu \mathrm{g} . \mathrm{l}^{-1}\right)$, CA 15-3; serum levels of CA 15-3 (kIU.1 ${ }^{-1}$ ); the volume of each thyroid lobe was calculated as length (milimetres) x width (milimetres) x depth (milimetres) $\mathrm{x} 0.479$. 
Table V. Comparison of age, body mass index and thyroid parameters in patients with recurrence and without documented recurrence of breast cancer.

\begin{tabular}{lccc}
\hline & $\begin{array}{c}\text { Without documented } \\
\text { recurrence (no. 54) }\end{array}$ & $\begin{array}{c}\text { Recurrence } \\
\text { (no. 30) }\end{array}$ & P-value \\
\hline Age & $64.574 \pm 11.497$ & $64.933 \pm 11.399$ & $0.891^{\mathrm{a}}$ \\
BMI & $25.373 \pm 4.744$ & $30.506 \pm 3.236$ & $0.004^{\mathrm{a}}$ \\
FT4 & $15.2(13.5-16.91)$ & $15.5(13.56-17.05)$ & $0.496^{\mathrm{b}}$ \\
TSH & $1.574(1.097-2.867)$ & $1.623(1.08-3.21)$ & $0.937^{\mathrm{b}}$ \\
TgAb & $27.3(6.1-93.9)$ & $22.45(6.1-56.3)$ & $0.484^{\mathrm{b}}$ \\
TPOAb & $36.0(30.4-71.7)$ & $33.7(29.8-65.7)$ & $0.507^{\mathrm{b}}$ \\
Prolactin & $7.869 \pm 3.314$ & $10.537 \pm 7.888$ & $0.352^{\mathrm{a}}$ \\
Selenium & $67.449 \pm 16.181$ & $81.036 \pm 18.245$ & $0,003^{\mathrm{a}}$ \\
& $($ no. 42$)$ & $($ no. 23) & $0.415^{\mathrm{c}}$ \\
AITD & $21(38.9)$ & $9(30.0)$ & $0.996^{\mathrm{c}}$ \\
AITD or Non-AITD - no. $(\%)$ & $22(39.3)$ & $11(36.7)$ & $0.884^{\mathrm{c}}$ \\
Positive TgAb - no. $(\%)$ & $4(25.9)$ & $9(30.0)$ & $0.226^{\mathrm{c}}$ \\
Positive TPOAb - no. $(\%)$ & $19(35.2)$ & $10(33.3)$ & $0.503^{\mathrm{c}}$ \\
Positive TPOAb or TgAb - no. $(\%)$ & $22(40.7)$ & $11.016 \pm 9.722$ & $($ no. 18$)$ \\
Thyroid volume $(\mathrm{ml})$ & $9.860 \pm 6.743$ & $($ no. $)$ & $0.692^{\mathrm{a}}$ \\
& & &
\end{tabular}

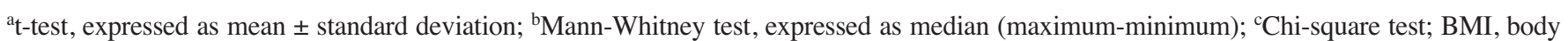
mass index; FT4, serum levels of free thyroxine (9.8-23.1 pmol.1-1 $)$; TSH, serum levels of thyroid stimulating hormone (mIU.1 $\left.1^{-1}\right)$; TgAb, serum levels of antibodies to thyroglobulin (kIU.1 ${ }^{-1}$ ); TPOAb, serum levels of antibodies to thyroid peroxidase (kIU.1 ${ }^{-1}$ ); prolactin, serum levels of prolactin $\left(\mu \mathrm{g} .1^{-1}\right)$; selenium, serum levels of selenium $\left(\mu \mathrm{g} .1^{-1}\right)$; AITD, clinical, laboratory and ultrasound documented autoimmune thyroid disease; non-AITD, non-autoimmune thyroid disease; the volume of each thyroid lobe was calculated as length (millimetres) $\mathrm{x}$ width (millimetres) x depth (millimetres) x 0.479 .

and thyroid disorders in women with breast cancer and with other malignant disease, such as colorectal cancer. Whereas the prevalence of positive thyroid antibodies was significantly higher in women with breast cancer as compared to that in women with colorectal cancer and the controls (TPOAb: 29.8 vs. 12.5 and $12.2 \%$, respectively, TgAb: 27.4 vs. 13.9 and $10.2 \%$, respectively), the prevalence in women with colorectal cancer was comparable with the controls and reached approximately the level found in the healthy control subjects in the other studies $(3.2-18.2 \%)(3,17,19,20)$. A higher prevalence of positive TPOAb in breast cancer was especially observed in patients with slightly increased titres (60-200 kIU.1 ${ }^{-1}$ ) (Figs. 2 and 3). Nevertheless, the positive titres of thyroid antibodies were not accompanied with impaired thyroid function. With the use of complex diagnostic methods (clinical examination, laboratory methods and ultrasound), the prevalence of AITD was found to be significantly higher in women with breast cancer $(35.7 \%)$ as compared to women with colorectal cancer and controls (18.1 and 16.3\%, respectively). In contrast, in women with colorectal cancer the prevalence of AITD did not significantly differ from the control group and the prevalence usually described in elderly women $(8-17 \%)$ (21). These facts supported the hypothesis that serum levels of thyroid antibodies and particularly TPOAb were exclusively elevated in women with breast cancer and probably did not occur in patients with other malignant tumours (e.g. colorectal cancer). Probably, increased serum levels of thyroid antibodies in women with breast cancer occur not only due to a non-specific immune activation accompanying a malignant process, but reflect an increased prevalence of euthyroid autoimmune thyroiditis in patients with breast cancer. Unfortunately, the causality of this specific linkage remains unclear.

One area in which thyroid and breast functions overlapped was the metabolism of iodine and selenium. In both the thyroid and the breast tissue natrium/iodide symporter (NIS) was expressed (22). It was also suggested that a combined iodine-selenium deficiency may facilitate the development of breast cancer $(23,24)$. On the other hand, an excessive iodine intake and selenium deficiency may contribute to the initiation of thyroid autoimmunity (25-27); whereas increasing dietary selenium intake was reported to diminish TPOAb serum levels (28).

There are contradictory statements concerning the impact of thyroid autoimmunity and dysfunction on the outcome of patients with breast cancer. Several studies indicated that hypothyroidism is associated with an increased risk of breast cancer development $(29,30)$. Moreover, an advanced tumour 
stage and a higher grade of tumour vascular invasion of breast cancer in women with thyroid diseases was observed (18). In contrast, primary hypothyroidism was associated with a reduced incidence of primary breast carcinoma (31). Nevertheless, several authors believed hypothyroidism, autoimmune thyroiditis and positive serum TPOAb levels to improve the outcome of patients with breast cancer $(3,7,32)$.

In spite of the above-mentioned studies, we did not find any significant influences of the baseline serum levels of FT4, TSH, $\mathrm{TgAb}$ and TPOAb on relapse-free and overall survival among patients with breast cancer in our study. Similarly, estimated relapse-free and overall survival did not significantly differ between patients with and without AITD. Our results are in concordance with the recent study by Kuijpens et al, who showed that the presence of TPOAb was not related to the outcome of patients with breast cancer during follow-up (30).

Moderately elevated prolactin is often found in the sera of women with subclinical or overt hypothyroidism. However, the role of prolactin in the development of breast cancer is controversial. In some studies, an increased risk of breast cancer in subjects with elevated serum levels of prolactin was found $(33,34)$. On the other hand, in post-menopausal women, mild hyperprolactinemia per se did not imply any significant health risks and it did not require treatment (35). Serum levels of prolactin were similar in patients with breast and colorectal cancer and did not have an impact on relapse-free and overall survival.

In our study, only BMI and selenium were the parameters that had an impact on the outcome of patients with breast cancer. Patients with a higher BMI had a significantly shorter relapse-free survival. Also, patients with relapsing breast cancer had a higher baseline BMI than those who remained relapse-free. These findings confirmed that obesity was an independent prognostic factor for a poor prognosis among women with breast cancer $(36,37)$. Although selenium was measured in a relatively small part of patients with breast cancer, a negative prognostic significance of increased serum levels of selenium on the relapse-free survival was found. Similarly, patients with a relapsing disease had higher serum levels of selenium at the baseline than patients who remained relapse-free. However, our findings are notably in contrast to previous studies which suggested selenium deficiency to be a risk factor for breast cancer development $(13,23,38)$. A prospective study with a large number of participants is necessary to confirm any prognostic significance of selenium intake in patients with breast cancer.

In conclusion, the results of our study supported the hypothesis that the prevalence of euthyroid AITD was specifically higher in women with breast cancer and was probably not only a result of an increased immune reactivity in the blood with oncological disease. In colorectal cancer the prevalence of AITD remained similar to the general population. We did not find any prognostic impact of AITD, non-AITD and prolactin on the relapse-free and overall survival of women with breast cancer. Although we found a negative prognostic significance of serum levels of selenium on relapse-free survival, further studies are needed to clarify a possible relationship between iodine and selenium intake and the outcome of patients with breast cancer and other malignant diseases.

\section{Acknowledgements}

This work was supported by the grant IGA from the Czech Ministry of Health NR 8352-3 (2005-2007).

\section{References}

1. Smyth PP, Smith DF, McDermott EW, Murray MJ, Geraghty JG and O'Higgins NJ: A direct relationship between thyroid enlargement and breast cancer. J Clin Endocrinol Metab 81: 937-941, 1996.

2. Límanová Z, Barkmanová $\mathrm{J}$ and Friedmanová Z: The frequent incidence of thyropathies in women with breast carcinoma. Vnitr Lek 44: 76-82, 1998.

3. Smyth PP, Shering SG, Kilbane MT, Murray MJ, McDermot EW, Smith DF and O'Higgins NJ: Serum thyroid peroxidase autoantibodies, thyroid volume and outcome in breast cancer. J Clin Endocrinol Metab 83: 2711-2716, 1998.

4. Gogas J, Kouskos E, Tseleni-Balafouta S, Markopoulos C, Revenas K, Gogas G and Kostakis A: Autoimmune thyroid disease in women with breast carcinoma. Eur J Surg Oncol 27: 626-630, 2001.

5. Turken O, Narin Y, Demirbas S, Onde ME, Sayan O, Kandemir EG, Yaylaci M, et al: Breast cancer in association with thyroid disorders. Breast Cancer Res 5: 110-113, 2003.

6. Jiskra J, Límanová Z, Barkmanová J, Smutek D and Friedmannová Z: Autoimmune thyroid diseases in women with breast cancer and colorectal cancer. Physiol Res 53: 693-702, 2004.

7. Goldman MB, Monson RR and Maloof F: Benign thyroiddiseases and the risk of death from breast-cancer. Oncology 49: 461-466, 1992.

8. Maruchi N, Annegers JF and Kurland LT: Hashimoto's thyroiditis and breast cancer. Mayo Clin Proc 51: 263-265, 1976.

9. Lemmarie M and Baugnet-Mahieu L: Thyroid function in women with breast cancer. Eur J Cancer Clin Oncol 22: 301-307, 1986.

10. Anker GB, Lonning PE, Aakvaag A and Lien EA: Thyroid function in post-menopausal breast cancer patients treated with tamoxifen. Scand J Clin Lab Invest 58: 103-107, 1998.

11. Sarlis NJ, Gourgiotis L, Pucino F and Tolis GJ: Lack of association between Hashimoto thyroiditis and breast cancer: a quantitative research synthesis. Hormones 1: 35-41, 2002.

12. Charalabopoulos K, Kotsalos A, Batistatou A, Charalabopoulos A, Vezyraki P, Peschos D, Kalfakakou V, et al: Selenium in serum and neoplastic tissue in breast cancer: correlation with CEA. Br J Cancer 95: 674-676, 2006.

13. Shah YM, Al-Dhaheri M, Dong Y, Ip C, Jones FE and Rowan BG: Selenium disrupts estrogen receptor (alpha) signaling and potentiates tamoxifen antagonism in endometrial cancer cells and tamoxifen-resistant breast cancer cells. Mol Cancer Ther 4: 1239-1249, 2005.

14. Lee SO, Nadiminty N, Wu XX, Lou W, Dong Y, Ip C, Onate SA, et al: Selenium disrupts estrogen signaling by altering estrogen receptor expression and ligand binding in human breast cancer cells. Cancer Res 65: 3487-3492, 2005.

15. Greenwald P: Clinical trials in cancer prevention: current results and perspectives for the future. J Nutr 134: 3507S-3512S, 2004.

16. Dayan CM, Saravan P and Bayly G: Whose normal thyroid function is better - yours or mine? Lancet 3: 353-354, 2002.

17. Kratzsch J, Fiedler GM, Leichtle A, Brugel M, Buchbinder S, Otto L, Sabri O, et al: New reference intervals for thyrotropin and thyroid hormones based on The National Academy of Clinical Biochemistry Citeria and Regular Ultrasonography of the Thyroid Gland. Clin Chem 51: 1480-1486, 2005.

18. Cengiz O, Bozkurt B, Unal B, Yildirim O, Karabeyoglu M, Eroglu A, Kocer B, et al: The relationship between prognostic factors of breast cancer and thyroid disorders in Turkish women. J Surg Oncol 87: 19-25, 2004.

19. Jaeger C, Hatziagelaki E, Petzoldt R and Bretzel RG: Comparative analysis of organ-specific autoantibodies and celiac disease-associated antibodies in type 1 diabetic patients, their first degree relatives and healthy control subjects. Diabetes Care 24: 27-32, 2001.

20. Tunc R, Gonen MS, Acbay O, Hamuryudan V and Yazici H: Autoimmune thyroiditis and anti-thyroid antibodies in primary Sjogren's syndrome: a case-control study. Ann Rheum Dis 63: 575-577, 2004.

21. Dayan CM and Daniels GH: Chronic autoimmune thyroiditis. N Engl J Med 99: 99-107, 1996. 
22. Riedel C, Dohan O, De La Vieja A, Ginter CS and Carrasco N: Journey of the iodide transporter NIS: from its molecular identification to its clinical role in cancer. Trends Biochem Sci 26: 490-496, 2001.

23. Cann SA, van Netten JP and van Netten C: Hypothesis: Iodine, selenium and the development of breast cancer. Cancer Causes Control 11: 121-127, 2001.

24. Smyth PA: The thyroid, iodine and breast cancer. Breast Cancer Res 5: 235-238, 2003.

25. Pearce EN, Farwell AP and Braverman LE: Thyroiditis. N Engl J Med 348: 2646-2655, 2003.

26. Zimmermann MB and Kohrle J: The impact of iron and selenium deficiencies on iodide and thyroid metabolism: biochemistry and relevance to public health. Thyroid 12: 867-878, 2002.

27. Prummel MF, Strieder T and Wiersinga WM: The environment and autoimmune thyroid diseases. Eur J Endocrinol 150: 605-618, 2004.

28. Duntas LH, Mantzou E and Koutras DA: Effects of a six-month treatment with selenomethionine in patients with autoimmune thyroiditis. Eur J Endocrinol 148: 389-393, 2003.

29. Thomas BS, Bulbrook RD, Goodman MJ, Russell MJ, Quinlan M, Hayward JL and Takatani O: Thyroid function and the incidence of breast cancer in Hawaiian, British and Japanese women. Int J Cancer 38: 325-329, 1986.

30. Kuijpens JL, Nyklictec I, Louwman MW, Weetman TA, Pop VJ and Coebergh JW: Hypothyroidism might be related to breast cancer in postmenopausal women. Thyroid 15: 1253-1259, 2005.
31. Cristofanilli M, Yamamura Y, Kau SW, Bevers T, Strom S, Patangan M, Hsu L, et al: Thyroid hormone and breast carcinoma. Primary hypothyroidism is associated with a reduced incidence of primary breast carcinoma. Cancer 103: 1122-1128, 2005.

32. Hercberg A: Hypothyroidism and tumour regression [letter]. $\mathrm{N}$ Engl J Med 319: 1351-1352, 1998.

33. Hankinson SE: Endogenous hormones and risk of breast cancer in postmenopausal women. Breast Dis 24: 3-15, 2006.

34. Tworoger SS and Hankinson SE: Prolactin and breast cancer risk. Cancer Lett 243: 160-169, 2006.

35. Schlechte JA: Clinical practice. Prolactinoma. N Engl J Med 349: 2035-2041, 2003.

36. Loi S, Milne RL, Friedlander ML, McCredie MR, Giles GG, Hopper JL and Phillips KA: Obesity and outcomes in premenopausal and postmenopausal breast cancer. Cancer Epidemiol Biomarkers Prev 14: 1686-1691, 2005

37. Carmichael A: Obesity as a risk factor for the development and poor prognosis of breast cancer. BJOG 7: 333-340, 2006

38. Breedlove HA, Smith AM, Burk RF, Hill KE and Shapiro CL: Serum selenium measurements in women with early-stage breast cancer with and without chemotherapy-induced ovarian failure. Breast Cancer Res Treat 97: 225-230, 2006. 